\title{
Medical treatment of actinic keratoses and superficial skin cancers: diclofenac
}

\author{
G Valenti \\ From de Senectute: Age and Health Forum \\ Catanzaro, Italy. 5-7 December 2009
}

In patients who develop early signs of fotocarcinogenesi, the actinic keratosis are one of the most frequent events that can lead to problems of therapeutic management, especially if for business reasons or lifestyle, they are repeatedly and chronically exposed to the sun. In these patients the lesions are often widespread and recurrent, and may require repeated treatment cycles.

It is in these cases that treatment with topical diclofenac 3\% gel hyaluronic acid can provide good results thanks to its efficacy, tolerability, the patient compliance and excellent cosmetic results compared to other conventional therapies.

It presents a brief review of clinical cases with the treatment modality and they discuss the indications and efficacy.

Published: 19 May 2010

- Convenient online submission

- Thorough peer review

- No space constraints or color figure charges

- Immediate publication on acceptance

- Inclusion in PubMed, CAS, Scopus and Google Scholar

- Research which is freely available for redistribution 